\title{
Screening of Actinomycetes from Mangrove Ecosystem for L-asparaginase Activity and Optimization by Response Surface Methodology
}

\author{
RAJAMANICKAM USHA*, KRISHNASWAMI KANJANA MALA, CHIDAMBARAM KULANDAISAMY VENIL \\ and MUTHUSAMY PALANISWAMY
}

Department of Microbiology, School of Life Science, Karpagam University, Tamil Nadu, India

Received 2 September 2010, revised 12 May 2011, accepted 15 May 2011

\begin{abstract}
Marine actinomycetes were isolated from sediment samples collected from Pitchavaram mangrove ecosystem situated along the southeast coast of India. Maximum actinomycete population was noted in rhizosphere region. About $38 \%$ of the isolates produced L-asparaginase. One potential strain KUA106 produced higher level of enzyme using tryptone glucose yeast extract medium. Based on the studied phenotypic characteristics, strain KUA106 was identified as Streptomyces parvulus KUA106. The optimization method that combines the Plackett-Burman design, a factorial design and the response surface method, which were used to optimize the medium for the production of L-asparaginase by Streptomycetes parvulus. Four medium factors were screened from eleven medium factors by Plackett-Burman design experiments and subsequent optimization process to find out the optimum values of the selected parameters using central composite design was performed. Asparagine, tryptone, $\mathrm{d}$ ))extrose and $\mathrm{NaCl}$ components were found to be the best medium for the L-asparaginase production. The combined optimization method described here is the effective method for screening medium factors as well as determining their optimum level for the production of L-asparaginase by Streptomycetes parvulus KUAP106.
\end{abstract}

Ke y w or d s: Streptomyces parvulus KUAP106, L-asparaginase, mangrove ecosystem, optimization by RSM

\section{Introduction}

Mangrove ecosystems are rich in bacterial flora. Fertility of the mangrove water results from the microbial decomposition of organic matter and recycling of nutrients. Among the microbes, the bacterial population in mangrove is many folds greater than the fungi. The bacteria performed various activities in the mangrove ecosystems like photosynthesis, nitrogen fixation, methanogenesis, production of antibiotics and enzymes (arysulphatase, L-glutamine, chitinase, L-asparaginase, cellulase, protease, phosphatase) etc. (Sahoo et al., 2008).

The enzyme L-asparaginase (L-asparagine aminohydrolase E.C.3.5.1.1) has been intensively investigated over the past two decades owing to its importance as anti neoplastic agent. Although the enzyme has been found in a variety of bacteria, fungi, actinomycetes and also in mammals, few of the purified preparations have shown to possess antitumor activity (Paul, 1983). Like bacteria, actinomycetes are also good source for the production of L-asparaginase (Dhevendran et al., 1999; Savitri et al., 2003).
In the last decade, statistical experimental methods such as Plackett-Burman and Response surface methodology (RSM) have been applied to optimize media for industrial purposes. RSM is a collection of statistical techniques for designing experiments, building models, evaluating the effects of various factors and searching for the optimum conditions. RSM has been successfully used in the optimization of bioprocesses (Majumdar et al., 2008). No defined medium has been established for the optimum production of L-asparaginase from different microbial sources. Each organism has its own special conditions for maximum enzyme production. A statistical approach has been employed in which a Plackett-Burman design is used for identification significant variables influencing L-asparaginase production by Serratia marcescens SB 08 (Venil et al., 2009).

Thereby, in this investigation L-asparaginase producing strain KUA106 was isolated from the pichavaram mangrove ecosystem and characterized to belong to Streptomyces parvulus (Shirling and Gottlieb, 1966) by morphology and biochemical characters. The levels of the significant variables were further optimized for L-asparaginase using response surface methodology.

* Corresponding author: R. Usha, $113 I^{\mathrm{In}} \mathrm{D}$, Tatabad, Sivanandha colony, Coimbatore12; phone: 9865068286; fax: 0422-2611043; e-mail: ushaanbu2007@rediffmail.com 


\section{Experimental}

\section{Materials and Methods}

Sample collection. Sediment samples were collected from different stations of the pichavaram mangrove ecosystem (Lat, $11^{\circ} 27^{\prime} \mathrm{N}$; Long. $79^{\circ} 47^{\prime} \mathrm{E}$ ), situated along the southeast coast of India. Sediment samples were collected from rhizosphere areas of mangrove plants. The central portion of the $5-15 \mathrm{~cm}$ sediment sample was taken. This sample was then transferred to a sterile bag and transported immediately to the laboratory.

Isolation of mangrove actinomycetes. The samples thus collected were air dried aseptically. After a week, sediment samples were incubated at $55^{\circ} \mathrm{C}$ for five minutes in order to facilitate the isolation of Actinomycetes. Then tenfold serial dilution was prepared with one gram of sediment sample using filtered and sterilized $50 \%$ seawater. Samples were inoculated on the starch casein agar plates in triplicate petriplates. Nalidixic acid $(20 \mu \mathrm{g} / \mathrm{ml})$ and cycloheximide $(50 \mu \mathrm{g} / \mathrm{ml})$ were added to the medium in order to retard the growth of bacteria and fungi, respectively. All the plates were incubated at $28 \pm 2^{\circ} \mathrm{C}$, and observed from $5^{\text {th }}$ day onwards for 25 days. Colonies with suspected Actinomycetes morphology were purified using yeast extract-malt extract agar medium. The pure cultures of the Actinomycetes were maintained as slant culture on ISP2 agar as well as in glycerol broth at $4^{\circ} \mathrm{C}$.

Screening of mangrove isolates for $\mathrm{L}$-asparaginase production by rapid-plate assay. The isolates were screened for asparaginase activity using the method of rapid plate assay (Gulati et al., 1997). The medium used was modified M-9 media with $\mathrm{pH}$ indicator (phenol red). L-asparaginase activity was identified by formation of a pink zone around colonies. Two control plates were also prepared using modified M-9 media - one was without dye while the other was without asparagine. All plates were incubated at $30^{\circ} \mathrm{C}$. Pink zone radius and colony diameter were measured from positive isolates after $48 \mathrm{hrs}$.

Identification of the selected L-asparaginase positive Actinomycetes. The large pink zone formed isolate was taken for further characterization. The microscopic characterization was done by cover slip culture method (Kawato and Sinobu, 1979). The mycelium structure, color and arrangement of conidiospore and arthrospore on the mycelium were observed through the oil immersion (1000X). The observed structure was compared with Bergey's manual of determinative bacteriology, ninth edition (2000). Various biochemical tests were performed for the identification of the potent isolate. Hydrogen sulphide production, citrate utilization, coagulation of milk (Cowan, 1974), catalase test (Jones,
1949), melanin pigment (Pridham, 1957), nitrate reduction (Gordon, 1966). The utilization of different carbon and nitrogen sources (Pridham, 1948). Cell wall was performed by the method of Lechevalier (1968). The cultural characteristics were studied in accordance with the guidelines established by the International Streptomyces Project (Shirilling, 1966).

Production of L-asparaginase. An amount $(100 \mathrm{ml})$ of tryptone glucose yeast extract (TGY) broth (production medium, $\mathrm{pH}$ 7.0) comprising of glucose, $0.1 \mathrm{~g}$; $\mathrm{K}_{2} \mathrm{HPO}_{4}, 0.1 \mathrm{~g}$; yeast extract, $0.5 \mathrm{~g}$; tryptone, $0.5 \mathrm{~g}$; water, to $100 \mathrm{ml}$, and contained in a $250 \mathrm{ml}$ Erlenmeyer flask, was inoculated separately with the screened isolates and incubated at $28^{\circ} \mathrm{C}$ in a shaker-incubator oscillating at $200 \mathrm{rev} / \mathrm{min}$ for $24 \mathrm{~h}$. At the end of the fermentation period, the crude enzyme was prepared by centrifugation at $1000 \mathrm{xg}$ for $20 \mathrm{~min}$. The cell-free supernatant was taken as the crude enzyme.

Enzyme assay. L-asparaginase activity was determined by measuring the amount of ammonia formed by nesslerization (Wriston and Yellin, 1973). $0.5 \mathrm{ml}$ sample of crude enzyme, $1.0 \mathrm{ml}$ of $0.1 \mathrm{M}$ sodium borate buffer ( $\mathrm{pH} 8.5$ ) and $0.5 \mathrm{ml}$ of $0.04 \mathrm{M} \mathrm{L}$-asparagine solution were mixed and incubated for $10 \mathrm{~min}$ at $37^{\circ} \mathrm{C}$. The reaction was then stopped by the addition of $0.5 \mathrm{ml}$ of $15 \%$ trichloroacetic acid. The precipitated protein was removed by centrifugation, and the liberated ammonia was determined by direct nesslerization.

Suitable blanks of substrate and enzyme-containing samples were included in all assays. The yellow color was read in a spectrophotometer (Shimadzu UV2450) at $500 \mathrm{~nm}$. One unit (U) of L-asparaginase activity is that amount of enzyme, which liberates $1 \mu$ mole of ammonia in $1 \mathrm{~min}$ at $37^{\circ} \mathrm{C}$.

Screening of important nutrient components using Plackett-Burman design. This study was done by Plackett-Burman design for screening medium components with respect to their main effects and not their interaction effects (Plackett and Burman, 1946) on L-asparaginase production by Streptomycetes sp. The medium components were screened for eleven variables at two levels, maximum (+) and minimum (-). According to the Plackett-Burman design, the number of positive signs $(+)$ is equal to $(\mathrm{N}+1) / 2$ and the number of negative signs (-) is equal to (N-1)/2 in a row. A column should contain equal number of positive and negative signs. The first row contains $(\mathrm{N}+1) / 2$ positive signs and $(\mathrm{N}-1) / 2$ negative signs and the choice of placing the signs is arbitrary. The next $(\mathrm{N}-1)$ rows are generated by shifting cyclically one place $(\mathrm{N}-1)$ times and the last row contains all negative signs. The experimental design and levels of each variable is shown in Table I. The medium was formulated as per the design and the flask culture experiments were performed. Response was calculated 
Table I

Plackett-Burman experiments design for evaluating factors influencing L-asparaginase by Streptomycetes sp.

\begin{tabular}{|c|c|c|c|c|c|c|c|c|c|c|c|c|}
\hline Run & $\mathrm{A}$ & $\mathrm{B}$ & $\mathrm{C}$ & $\mathrm{D}$ & $\mathrm{E}$ & $\mathrm{F}$ & $\mathrm{G}$ & $\mathrm{H}$ & $\mathrm{J}$ & $\mathrm{K}$ & $\mathrm{L}$ & $\begin{array}{c}\text { L-asparaginase } \\
\mathrm{U} / \mathrm{mL}\end{array}$ \\
\hline 1 & 10 & 50 & 0 & 0.5 & 4 & 5 & 0.01 & 5 & 2 & 0.1 & 0.1 & 56 \\
\hline 2 & 4 & 50 & 150 & 1 & 4 & 1 & 0.01 & 5 & 0.5 & 0.3 & 0.1 & 36 \\
\hline 3 & 10 & 50 & 0 & 1 & 10 & 5 & 0.01 & 0.5 & 0.5 & 0.3 & 0.05 & 39 \\
\hline 4 & 4 & 50 & 150 & 0.5 & 10 & 5 & 0.05 & 0.5 & 0.5 & 0.1 & 0.1 & 66 \\
\hline 5 & 10 & 20 & 150 & 1 & 10 & 1 & 0.01 & 0.5 & 2 & 0.1 & 0.1 & 19 \\
\hline 6 & 4 & 20 & 0 & 1 & 4 & 5 & 0.05 & 0.5 & 2 & 0.3 & 0.1 & 45 \\
\hline 7 & 4 & 20 & 150 & 0.5 & 10 & 5 & 0.01 & 5 & 2 & 0.3 & 0.05 & 20 \\
\hline 8 & 10 & 20 & 150 & 1 & 4 & 5 & 0.05 & 5 & 0.5 & 0.1 & 0.05 & 23 \\
\hline 9 & 4 & 50 & 0 & 1 & 10 & 1 & 0.05 & 5 & 2 & 0.1 & 0.05 & 32 \\
\hline 10 & 4 & 20 & 0 & 0.5 & 4 & 1 & 0.01 & 0.5 & 0.5 & 0.1 & 0.05 & 25 \\
\hline 11 & 10 & 20 & 0 & 0.5 & 10 & 1 & 0.05 & 5 & 0.5 & 0.3 & 0.1 & 53 \\
\hline 12 & 10 & 50 & 150 & 0.5 & 4 & 1 & 0.05 & 0.5 & 2 & 0.3 & 0.05 & 36 \\
\hline
\end{tabular}

A: $\mathrm{pH} ; \quad$ B:Temperature $\left({ }^{\circ} \mathrm{C}\right) ; \quad$ C: Agitation (rpm); D: Inoculum concentration (\%); E: Incubation time (days) F: Dextrose (\%); G: Asparagine (\%); $\mathrm{H}$ : Yeast extract (\%); J: Tryptone (\%); $\mathrm{K}: \mathrm{KH}_{2} \mathrm{PO}_{4}(\%) ; \mathrm{L}: \mathrm{NaCl}(\%)$

at the rate of enzyme production and expressed as $\mathrm{U} / \mathrm{mL}$. All experiments were performed in triplicate and the average of the rate of enzyme production was considered as the response. The effect of each variable was calculated using the following equation: $\mathrm{E}=\left(\Sigma \mathrm{M}_{+}-\mathrm{M}_{-}\right) / \mathrm{N}$. Where $E$ is the effect of tested variable, $M_{+}$and $M_{-}$are responses of trials at which the parameter was at its higher and lower levels respectively and $\mathrm{N}$ is the number of experiments carried out. The standard error (SE) of the variables were the square root of variance and the significance level ( $p$-value) of each variables calculated by using Student's $t$-test. $t=$ Exi/SE, where Exi is the effect of tested variable. The variables with higher confidence levels were considered to influence the response or output variable.

Optimization of concentration of the selected medium components using response surface methodology. The screened medium components affecting enzyme production were optimized using central composite design (CCD) (Box and Wilson, 1951; Box and Hunter, 1957). According to this design, the total number of treatment combinations is $2 k+2 k+n 0$ where ' $k$ ' is the number of independent variables and $n 0$ the number of repetitions of the experiments at the center point. For statistical calculation, the variables $X i$ have been coded as $x i$ according to the following transformation: $x i=X_{i}-X_{0} / \delta X$. where: $X_{i}$ is dimensionless coded value of the variable. $X_{i}, X_{0}$ the value of the $X_{i}$ at the center point, and $\delta X$ is the step change. A $2 k$-factorial design with eight axial points and six replicates at the center point with a total number of 30 experiments were employed for optimizing the medium components. The behavior of the system was explained by the following quadratic equation: $Y=\beta_{0}+\Sigma \beta_{i} x_{i}+\Sigma \beta_{i i} x_{i}^{2}+$ $+\Sigma \beta_{i j} x_{i j} x_{j}$. where $Y$ is the predicted response, $\beta_{0}$ the intercept term, $\beta_{i}$ the linear effect, $\beta_{i i}$ the squared effect, and $\beta_{i j}$ is the interaction effect. The regression equation was optimized for maximum value to obtain the optimum conditions using Design Expert Version.

Validation of the experimental model. The statistical model was validated with respect to L-asparaginase production under the conditions predicted by the model in shake flask conditions. Samples were withdrawn at the desired intervals and L-asparaginase assay was determined as described above.

\section{Results and Discussion}

Isolation and screening of mangrove actinomycetes for L-asparaginase production by rapid-plate assay. Samples were examined for Actinomycetes. After $5^{\text {th }}$ day to $25^{\text {th }}$ day, 63 colonies were found on starch casein agar plate. These 63 isolates were screened for L-asparaginase activity. Only 24 isolates showed positive in rapid plate assay method (Fig. 1). The plate study is advantageous as the method is quick and L-asparaginase production visualized directly from the plates. The studies with different concentration of the dye revealed that as the concentration of the dye increases, the clarity and visibility of the pink zone increased.

Mangroves have very specialized adaptations that enable them to live different condition. It exists under very hostile and inhospitable conditions (Khan and Ali, 2007). So far no reports are available on Actinomycetes isolated from mangrove sediments exhibiting 


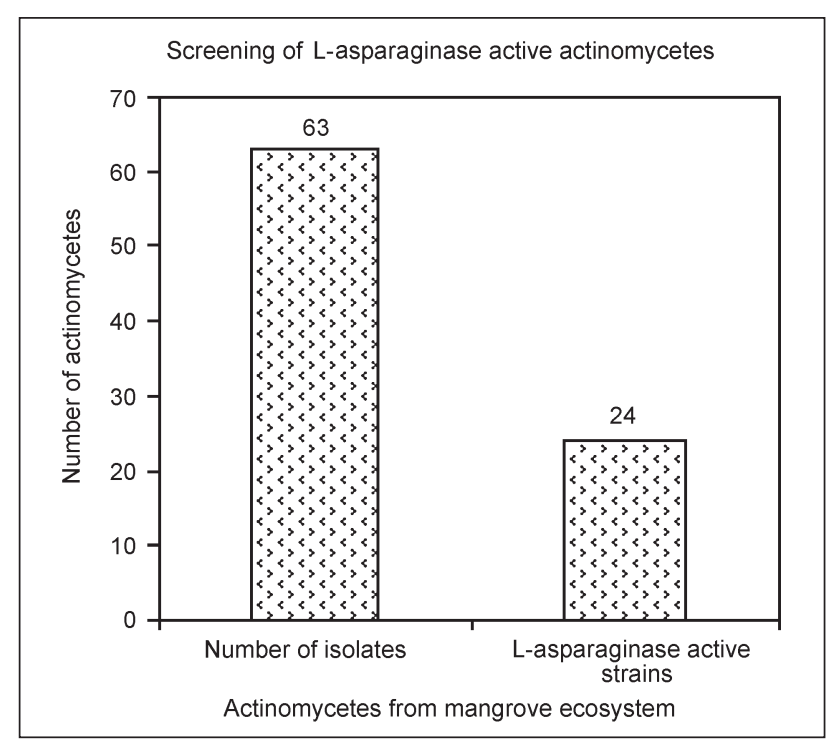

Fig. 1. Isolation and screening of mangrove Actinomycetes for L-asparaginase production.

prominent L-asparaginase production. Hence it is suggested that the strain isolated from pichavaram mangrove environment, possessing L-asparaginase activity.

Identification of the selected L-asparaginase positive Actinomycetes. The large pink zone formed isolate produced grey and white colonies with yellow pigmentation and showed fast growth within two days on yeast extract malt extract agar (International Streptomyces Project 2 medium). The morphological, physiological and biochemical characteristics of actinomycete isolate KUA 106 was summarized in Table II. The cell wall hydrolysate contains L-diaminopimelic acid (LL-DAP) and sugar pattern were not detected.

The physiological characteristic studies revealed that the isolate KUA 106 did produce melanoid pigments. This strain hydrolysed starch, reduced nitrate and liquefied gelatin but it did not produce $\mathrm{H}_{2} \mathrm{~S}$. It utilized glucose, arabinose, mannose, maltose, xylose, inositol and starch. It could not utilize lactose, raffinose, sucrose, galactose and mannitol. As nitrogen sources, it utilized cystein, phenyl alanine, lysine, serine and hydroxy proline, and histidine are poorly utilized. It could not utilize valine. Well growth was recorded at a temperature range of 15 to $37^{\circ} \mathrm{C}$ and $\mathrm{pH}$ range of 6 to 9 . The utilization of various carbohydrates by the selected isolate suggests a good pattern of carbon assimilation. Glucose, xylose and inositol sugars were well utilized. These results emphasized that the Actinomycetes isolate is related to a group of Streptomyces parvulus.

Plackett-Burman design. The influence of eleven (11) factors namely $\mathrm{pH}$, temperature, agitation, inoculum concentration, incubation time, dextrose, asparagine, yeast extract, tryptone, $\mathrm{KH}_{2} \mathrm{PO}_{4}$ and $\mathrm{NaCl}$ in the production of L-asparaginase was investigated in
Table II

The morphological, physiological and biochemical characteristics of the Actinomycetes isolate KUAP 106

\begin{tabular}{|c|c|}
\hline Characteristic & Result \\
\hline Spore mass & gray \\
\hline Spore surface & smooth \\
\hline Spore chain & spiral \\
\hline Diffusible pigment & produced \\
\hline Melanin pigment & - \\
\hline Diaminopimelic acid (DAP) & LL-DAP \\
\hline Hydrolysis of Protein & + \\
\hline Catalase test & - \\
\hline Production of melanin pigment & + \\
\hline Starch hydrolysis & + \\
\hline Liquefied gelatin & + \\
\hline H2S Production & - \\
\hline Nitrate reduction & + \\
\hline Citrate utilization & + \\
\hline Urea test & - \\
\hline Coagulation of milk & - \\
\hline $\begin{array}{l}\text { Utilization of: } \\
\text { D-Xylose }\end{array}$ & + \\
\hline D-Mannose & + \\
\hline D-Glucose & + \\
\hline D-Galactose & + \\
\hline Rhamnose & + \\
\hline Raffinose & + \\
\hline Mannitol & - \\
\hline L-Arabinose & ++ \\
\hline meso-Inositol & - \\
\hline Lactose & - \\
\hline Maltose & ++ \\
\hline D-fructose & - \\
\hline Sucrose & ++ \\
\hline Starch & +++ \\
\hline L-Cycteine & + \\
\hline L-Valine & + \\
\hline L-Histidine & - \\
\hline L-Phenylalanine & - \\
\hline L-Hydroxproline & + \\
\hline L-Lysine & + \\
\hline L-Arginine & - \\
\hline L-Serine & + \\
\hline L-Tyrosine & + \\
\hline $\begin{array}{l}\text { Growth with } \\
\text { Sodium azide }(0.01)\end{array}$ & + \\
\hline Phenol (0.1) & + \\
\hline $\begin{array}{l}\text { Enzyme activity } \\
\alpha \text {-amylase }\end{array}$ & + \\
\hline Gelatinase, & + \\
\hline Protease & + \\
\hline Lecithinase & - \\
\hline L-asparaginase & + \\
\hline
\end{tabular}

- = Negative; $+=$ Positive; $++=$ moderate growth; $+++=$ good growth results. 


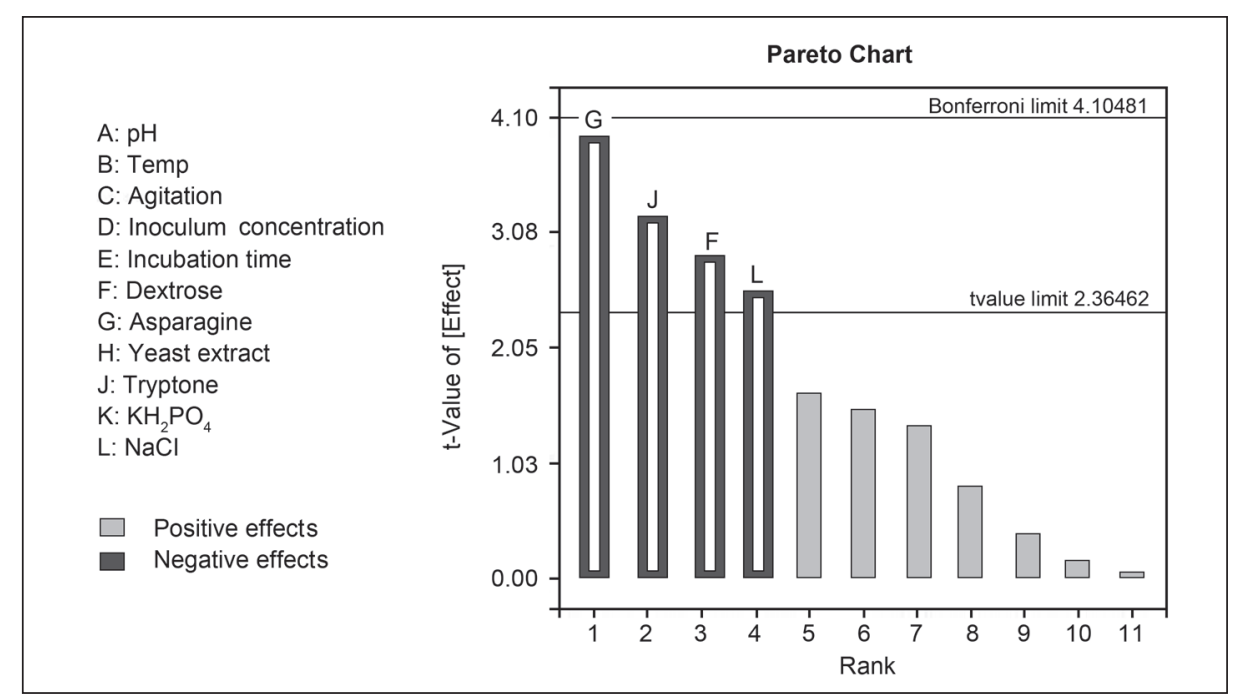

Fig. 2. Pareto chart for Plackett-Burman design for 11 medium factors on L-asparaginase production by Streptomycetes parvulus KUA106.

12 runs using Plackett-Burman design. Table I represents the Plackett-Burman design for 11 selected variables and the corresponding response for L-asparaginase production. Variations ranging from 19 to $66 \mathrm{U} / \mathrm{mL}$ in the production of L-asparaginase in the 12 trials were observed by Plackett-Burman design.

The Pareto chart illustrates the order of significance of the variables affecting L-asparaginase production (Fig. 2). Among the variables screened, the most effective factors with high significance level indicated by Pareto chart were in the order asparagine, tryptone, dextrose and $\mathrm{NaCl}$.

Asparagine showed a remarkable support for the growth of Streptomycetes parvulus. Tryptone, dextrose and $\mathrm{NaCl}$ were also identified as most potent significant variables in L-asparaginase production from Streptomycetes parvulus and selected for further optimization while $\mathrm{pH}$, temperature, agitation, inoculum concentration, incubation time, yeast extract and $\mathrm{KH}_{2} \mathrm{PO} 4$ concentration which exhibited less significant level were omitted in further experiments. Statistical analysis of the Plackett-Burman design demonstrated that the model $\mathrm{F}$ value of 7.24 is significant. The values of $p<0.05$ indicate model terms are significant (Table II).

Regression analysis was performed on the results and first order polynomial equation was derived representing $\mathrm{L}$-asparaginase production as a function of the independent variables. $\mathrm{Y}=43.94 \mathrm{G}+10.07 \mathrm{~J}-6.28 \mathrm{~F}$ $-4.98 \mathrm{~L}$. Where $\mathrm{Y}$ is the response value (L-asparaginase production) and $\mathrm{A}, \mathrm{B}, \mathrm{C}$ and $\mathrm{D}$ are the coded levels of asparagine, tryptone, dextrose and $\mathrm{NaCl}$ respectively. The magnitude of the effects indicated the level of the significance of the variables on L-asparaginase production consequently, based on the results from the experiment, statistically significant variables (i.e.) asparagine, tryptone, dextrose and $\mathrm{NaCl}$ with positive effect were further investigated with central composite design to find the optimal range of these variables.

Central composite design. Based on Plackett-Burman design, asparagine, tryptone, dextrose and $\mathrm{NaCl}$ were selected for further optimization using response surface methodology. To examine the combined effect of these factors, a central composite design (CCD) was employed within a range of -2 to +2 in relation to production of L-asparaginase (Table III). Run 4 showed maximum L-asparaginase production of $135 \mathrm{U} / \mathrm{mL}$ (asparagine $-0.05 \%$, tryptone $-0.5 \%$, dextrose $-5 \%$, $\mathrm{NaCl}-0.05 \%)$.

The results obtained from the central composite design were fitted to a second order polynomial equation to explain the dependence of L-asparaginase production on the medium components. L-asparaginase $=$ $=115.67+19.17 \mathrm{~A}-5.08 \mathrm{~B}+11.83 \mathrm{C}+0.83 \mathrm{D}-6.38 \mathrm{AB}+$ $+8.13 \mathrm{AC}+1.63 \mathrm{AD}-8.00 \mathrm{BC}+0.50 \mathrm{BD}-4.25 \mathrm{CD}-$ $-19.42 \mathrm{~A}^{2}-17.67 \mathrm{~B}^{2}-14.54 \mathrm{C}^{2}-9.29 \mathrm{D}^{2}$. Where $\mathrm{Y}$ is the

Table III

Analysis of variance for L-asparaginase production by Streptomycetes parvulus KUA106

\begin{tabular}{|l|c|c|c|c|c|}
\hline \multicolumn{1}{|c|}{ Source } & $\begin{array}{c}\text { Sum of } \\
\text { square } \\
\text { ource }\end{array}$ & DF & $\begin{array}{c}\text { Mean } \\
\text { square }\end{array}$ & $\begin{array}{c}\text { F } \\
- \text { Value }\end{array}$ & $\begin{array}{c}p \\
- \text { Value }\end{array}$ \\
\hline Model & 2281.25 & 4 & 570.313 & 7.24958 & 0.0124 \\
\hline G-Asparagine & 294.03 & 1 & 294.03 & 3.73758 & 0.0945 \\
\hline J-Tryptone & 1216.05 & 1 & 1216.05 & 15.458 & 0.0057 \\
\hline F-Dextrose & 473.763 & 1 & 473.763 & 6.02228 & 0.0438 \\
\hline L-NaCl & 297.406 & 1 & 297.406 & 3.78049 & 0.0929 \\
\hline Residual & 550.679 & 7 & 78.6685 & & \\
\hline Cor Total & 2831.93 & 11 & & & \\
\hline
\end{tabular}


Table IV

Experimental plan for optimization of L-asparaginase production using central composite design

\begin{tabular}{|c|c|c|c|c|c|c|}
\hline \multirow{2}{*}{ Run } & \multirow{2}{*}{$\begin{array}{c}\text { A: Asparagine } \\
\%\end{array}$} & \multirow{2}{*}{$\begin{array}{c}\text { B: Tryptone } \\
\%\end{array}$} & \multirow{2}{*}{$\begin{array}{c}\text { C: Dextrose } \\
\%\end{array}$} & \multirow{2}{*}{$\begin{array}{c}\mathrm{D}: \mathrm{NaCl} \\
\%\end{array}$} & \multicolumn{2}{|c|}{$\mathrm{L}$-asparaginase $\mathrm{U} / \mathrm{mL}$} \\
\hline & & & & & Experimental & Predicted \\
\hline 1 & 0.03 & 1.25 & 3 & 0.525 & 55 & 53 \\
\hline 2 & 0.03 & 1.25 & -1 & 0.525 & 21 & 22 \\
\hline 3 & 0.03 & -0.25 & 3 & 0.525 & 37 & 37 \\
\hline 4 & 0.05 & 0.5 & 5 & 0.05 & 135 & 132 \\
\hline 5 & 0.05 & 2 & 1 & 0.05 & 38 & 37 \\
\hline 6 & 0.03 & 2.75 & 3 & 0.525 & 48 & 44 \\
\hline 7 & 0.05 & 0.5 & 5 & 1 & 121 & 119 \\
\hline 8 & 0.01 & 2 & 1 & 1 & 21 & 19 \\
\hline 9 & 0.05 & 2 & 1 & 1 & 87 & 89 \\
\hline 10 & 0.05 & 2 & 5 & 1 & 54 & 52 \\
\hline 11 & 0.01 & 0.5 & 1 & 0.05 & 34 & 33 \\
\hline 12 & -0.01 & 1.25 & 3 & 0.525 & 12 & 10 \\
\hline 13 & 0.05 & 0.5 & 1 & 0.05 & 67 & 67 \\
\hline 14 & 0.07 & 1.25 & 3 & 0.525 & 59 & 54 \\
\hline 15 & 0.05 & 0.5 & 1 & 1 & 54 & 54 \\
\hline 16 & 0.03 & 1.25 & 3 & -0.425 & 65 & 67 \\
\hline 17 & 0.01 & 0.5 & 5 & 0.05 & 32 & 31 \\
\hline 18 & 0.03 & 1.25 & 3 & 0.525 & 129 & 130 \\
\hline 19 & 0.03 & 1.25 & 3 & 0.525 & 124 & 125 \\
\hline 20 & 0.03 & 1.25 & 3 & 0.525 & 130 & 128 \\
\hline 21 & 0.03 & 1.25 & 3 & 1.475 & 87 & 86 \\
\hline 22 & 0.01 & 2 & 5 & 1 & 22 & 21 \\
\hline 23 & 0.03 & 1.25 & 7 & 0.525 & 89 & 88 \\
\hline 24 & 0.01 & 2 & 1 & 0.05 & 37 & 35 \\
\hline 25 & 0.01 & 2 & 5 & 0.05 & 42 & 40 \\
\hline 26 & 0.01 & 0.5 & 1 & 1 & 36 & 35 \\
\hline 27 & 0.03 & 1.25 & 3 & 0.525 & 125 & 121 \\
\hline 28 & 0.03 & 1.25 & 3 & 0.525 & 131 & 134 \\
\hline 29 & 0.05 & 2 & 5 & 0.05 & 75 & 74 \\
\hline 30 & 0.01 & 0.5 & 5 & 1 & 41 & 43 \\
\hline
\end{tabular}

predicted response of L-asparaginase production G, J, $\mathrm{F}$ and $\mathrm{L}$ are the coded values of asparagine, tryptone, dextrose and $\mathrm{NaCl}$ respectively. For the production of this L-asparaginase enzyme there is the need for the presence of carbon source, nitrogen source and also small amount of mineral nutrients for the remarkable production of the enzyme particularly on the large scale production.

The analysis of variance of the quadratic regression model suggested that the model is very significant as was evident from the Fisher's F-test (Table IV). The model's goodness to fit was checked by determination coefficient $\left(\mathrm{R}^{2}\right)$. In the case, the value of $\mathrm{R}^{2}(0.84)$ closer to 1 denotes better correlation between the observed and predicted responses. The coefficient of variation (CV) indicates the degree of precision with which the experiments are compared. The lower reliability of the experiment is usually indicated by high value of $\mathrm{CV}$ (4.06) denotes that the experiments performed are highly reliable. The $p$ value denotes the significance of the coefficient and also important in understanding the pattern of the mutual interactions between the variables.

The fitted responses for the above regression model were plotted in Figure 3. 3D graphs were generated for the pair wise combination of four factors for L-asparaginase production. Graphs highlight the roles played by various factors affecting $\mathrm{L}$-asparaginase production. 

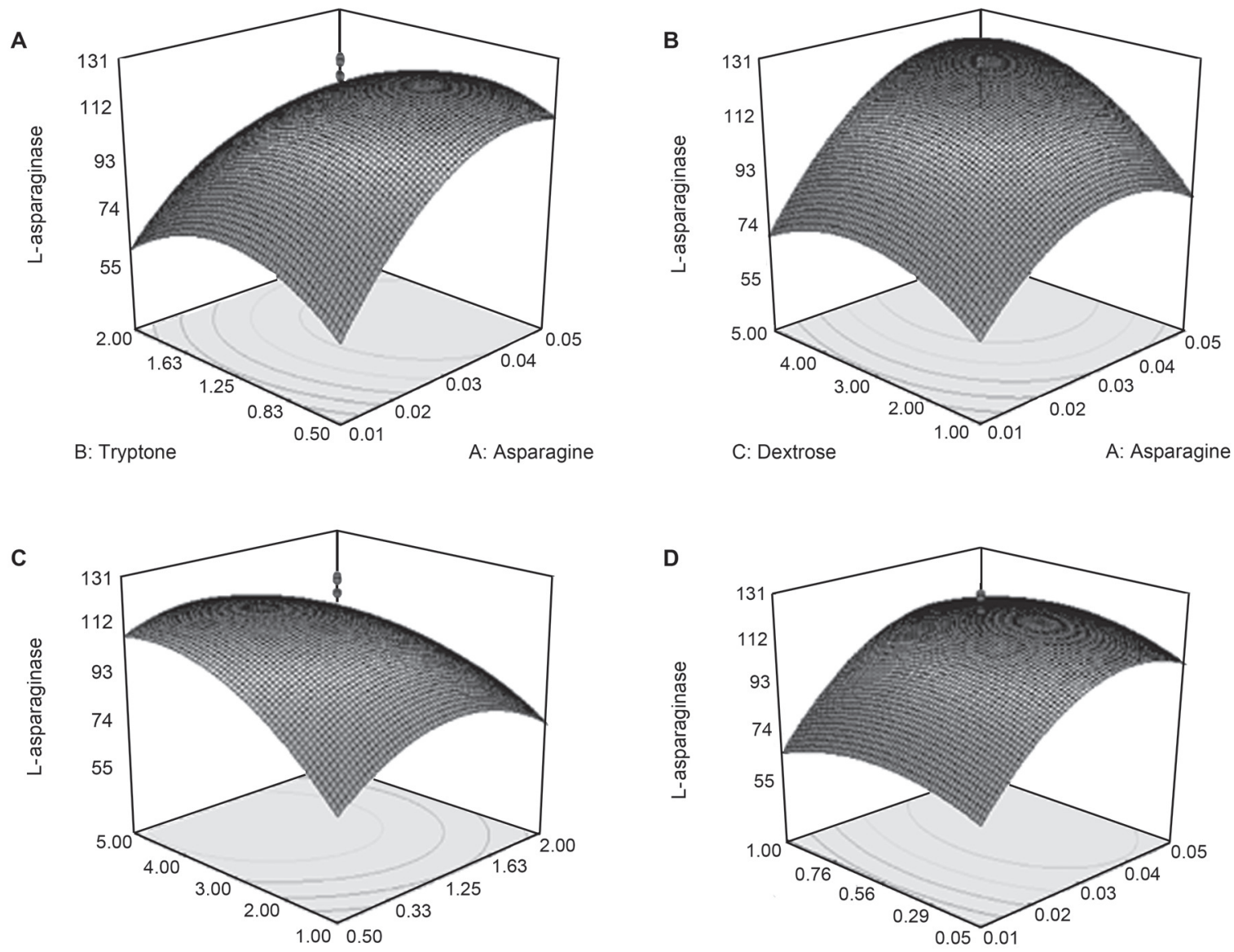

C: Dextrose

B: Tryptone

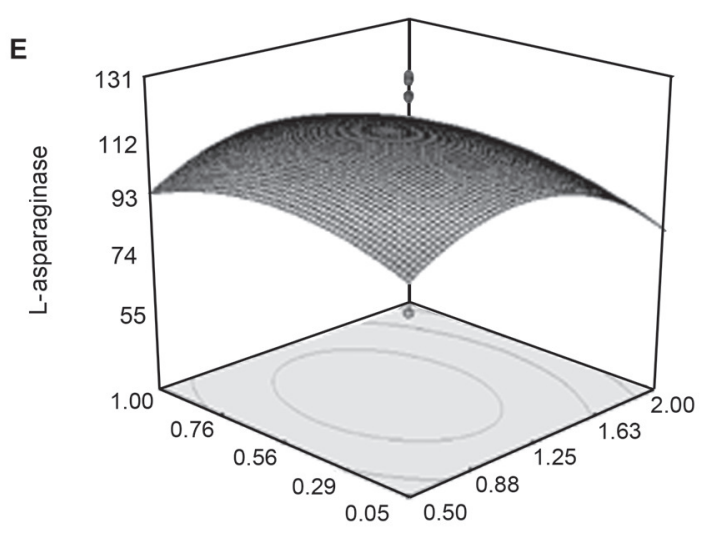

D: Nacl

B: Tryptone

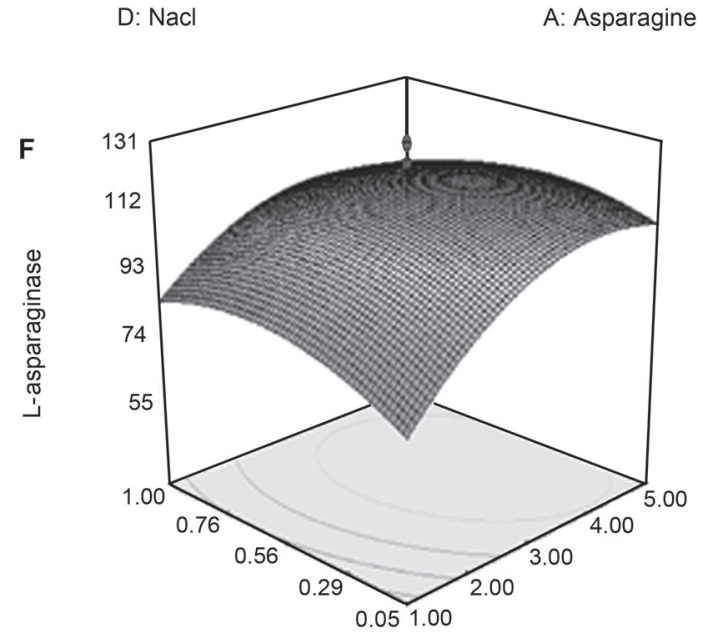

Fig. 3. Three dimensional response surface plot for the effect of (A) asparagine, tryptone (B) asparagine, dextrose (C) asparagine, $\mathrm{NaCl}(\mathrm{D})$ tryptone, dextrose (E) tryptone, $\mathrm{NaCl}(\mathrm{F})$ dextrose, $\mathrm{NaCl}$.

The experimental values were found to be very close to the predicted values hence, the model was successfully validated. The $\mathrm{L}$-asparaginase production showed about 2.04 fold increases over the central point and 5.50 fold increases over the basal medium.

Validation model. The maximum experimental response for L-asparaginase production was $135 \mathrm{U} / \mathrm{mL}$ whereas the predicted value was $132 \mathrm{U} / \mathrm{mL}$ indicating a strong agreement between them. The scale-up study was carried out in jar fermentation by using medium under optimized conditions. The maximum production of $146 \mathrm{U} / \mathrm{ml} \mathrm{L}$-asparaginase was achieved in this scaleup study. The result of optimization study under flask conditions was $135 \mathrm{U} / \mathrm{mL}$ was observed in the scale up study with higher volume of fermentation.

Conclusions. Based on screening results, it has been shown that mangrove sediments of pichavaram possess L-asparaginase producing Actinomycetes and 
Table V

ANOVA for the experimental results of the central composite design (quadratic model)

\begin{tabular}{|l|c|c|c|c|c|}
\hline \multicolumn{1}{|c|}{ Source } & Sum of squares & $\mathrm{df}$ & Mean square & F-value & p-value \\
\hline Model & 35586.45 & 14 & 2541.889 & 4.129386 & 0.0050 \\
\hline A-Asparagine & 8816.667 & 1 & 8816.667 & 14.32298 & 0.0018 \\
\hline B-Tryptone & 620.1667 & 1 & 620.1667 & 1.007482 & 0.3314 \\
\hline C-Dextrose & 3360.667 & 1 & 3360.667 & 5.459518 & 0.0337 \\
\hline $\mathrm{D}-\mathrm{NaCl}$ & 16.66667 & 1 & 16.66667 & 0.027076 & 0.8715 \\
\hline $\mathrm{AB}$ & 650.25 & 1 & 650.25 & 1.056353 & 0.3203 \\
\hline $\mathrm{AC}$ & 1056.25 & 1 & 1056.25 & 1.715914 & 0.2099 \\
\hline $\mathrm{AD}$ & 42.25 & 1 & 42.25 & 0.068637 & 0.7969 \\
\hline $\mathrm{BC}$ & 1024 & 1 & 1024 & 1.663523 & 0.2167 \\
\hline $\mathrm{BD}$ & 4 & 1 & 4 & 0.006498 & 0.9368 \\
\hline $\mathrm{CD}$ & 289 & 1 & 289 & 0.46949 & 0.5037 \\
\hline $\mathrm{A}^{2}$ & 10340.76 & 1 & 10340.76 & 16.79892 & 0.0009 \\
\hline $\mathrm{B}^{2}$ & 8560.762 & 1 & 8560.762 & 13.90725 & 0.0020 \\
\hline $\mathrm{C}^{2}$ & 5800.048 & 1 & 5800.048 & 9.422375 & 0.0078 \\
\hline $\mathrm{D}^{2}$ & 2368.048 & 1 & 2368.048 & 3.846974 & 0.0687 \\
\hline Residual & 9233.417 & 15 & 615.5611 & & \\
\hline Lack of Fit & 4778.083 & 10 & 477.8083 & 0.536221 & 0.8122 \\
\hline Pure Error & 4455.333 & 5 & 891.0667 & & \\
\hline Cor Total & 44819.87 & 29 & & & \\
\hline
\end{tabular}

$\mathrm{CV}=4.06 ; \quad \mathrm{R}^{2}=0.84$

this ecosystem exists as one of the potential source of L-asparaginase enzyme. Smaller and less time consuming experimental designs will generally suffice for the optimization of fermentation process. The isolated Streptomycetes parvulus KUAP106 can be used for the production of L-asparaginase enzyme. Further it is important to discover newer Streptomycetes sp. that produce enzymes that could be of industrial value.

\section{Acknowledgement}

The authors are grateful to Karpagam University, Coimbatore, Tamil Nadu, and India for providing the infrastructure facilities for this study.

\section{Literature}

Abdel-Fattah Y.R., H.M. Saeed, Y. Gohar and E.L. Baz-ma. 2005. Improved production of Pseudomonas aeruginosa uricase by optimization of process parameters through statistical experimental designs. Process Biochem. 40: 1707-1714.

Aguilar G., J. Morlon-Guyot, B. Trejo-Aguilar and J.P. Guyot. 2000. Purification and characterization of an extra cellular alpha amylase produced by Lactobacillus manihotivorans LMG 1801 (T), an amylolytic lactic acid bacterium. Enzyme Microb. Technol. 27: 406-413.

Box G. and J.S. Hunter. 1957. Multi-factor experimental designs for exploring response surfaces. Ann. Math. Stat. 28: 195-241.

Box G. and K.B.Wilson. 1951. On the experimetal designs for exploring response surfaces. Ann. Math. Stat. 13: 1-45.
Cowan S.T. 1974. Cowan and Steel Manual for the Identification of Medical Bacteria 2 . Edition Cambridge, Univ. Press.

Dhevandran K. and K. Annie. 1999. Antibiotic and L-asparaginase of Streptomycetes isolated from fish, shellfish, and sediments of veli estuarine along Kerala coast. Indian J. Mar. Sci. 28: 335-337.

Gordon R.E. 1966. Some criteria for the recognition of Nocardia madura (Vincent) Blanchord. J. Gen. Microbiol. 45: 355-364.

Gulati R., R.K. Saxena and R. Gupta. 1973. A rapid screening for L-asparaginase and glutaminase activities of microorganisms. J. Gen. Microbiol. 76: 85-99.

Jones K. 1949. Fresh isolates of actinomycetes in which the presence of sporogenous aerial mycelia is a fluctuating characteristics. J. Bacteriol. 57: 141-145.

Kim H.O, J.M. Lim, J.H. Joo, S.W. Kim, H.J. Hwang, J.W. Choi and J.W. Yun. 2005. Optimization of submerged culture condition for the production of mycelial biomass and exopolysaccharides by Agrocybe cylindracea. Bioresour. Technol. 96: 1175-1182.

Khan A.S and M.S. Ali. 2007. Mangroves- an ecosystem in peril. J. Curr. Sci. 10: 419-420.

Kawato M and R. Shinobu. 1959. A simple technique for the microscopical observation. Mem. Osaka Unit. Lib. Arts. Educ. B Nat. Sci. 8: 114-119.

Lechevalier M.P. and H.A. Lechevalier. 1968. Chemical composition as a criterion in the classification of aerobic actinomycetes. J. Sys. Bacteriol. 20: 435-443.

Le Mense E.H., J. Corman, J.M. Van Lanen and A.F. Langlykke. 1947. Production of mold amylases in submerged culture. Biochem. 54: $149-159$.

Lee K.M. and D.F. Gilmore. 2005. Formulation and process modeling of biopolymer (polyhydroxyalkanoates: PHAs) production from industrial wastes by novel crossed experimental design. Process Biochem 40: 229-246. 
Locci R. 1989. Streptomyces and related genera. Bergey's manual of systematic bacteriology. William and Wilkins company. Baltimore 4: 2451-2508.

Majumdar A. and A. Goyal. 2008. Enhanced production of exocellular glucansucrase from Leuconostoc dextranicum NRRL B-1145 using response surface method. Bioresour. Technol. 99, 3685-3691.

McTigue M.A., C.T. Kelly, W.M. Fogarty and E.M. Doyle. 1994. Production studies on the alkaline amylases of three alkalophilic Bacillus sp. Biotechnology Lett. 16: 569-574.

Nawani N.N. and B.P. Kapadnis. 2005. Optimization of chitinase production using statistics based experimental designs. Process Biochem. 40: 651-660.

Paul J.H. 1982. Isolation and characterization of a chlamydomonas L-asparaginase. Biochem. J. 203: 109-115.

Plackett R.L. and J.P. Burman. 1946. The design of optimum multifactorial experiments. Biometrika 33: 305-325.

Pridham T.G., P. Anderson, C. Foley, L.A. Lindenfelser, C.W. Hesselting and R.G. Benedict. 1957. A section of media for maintenance and taxonomic study of Streptomycetes. Antibiotics Ann., pp. 947-953.

Pridham T.G. and D. Gottlieb. 1948. The utilization of carbon compounds by some actinomycetes as an aid for species determination. J. Bacteriol. 56: 107-114.
Sahoo K. and N.K. Dhal. 2009. Potential microbial diversity in mangrove ecosystems. A review. Indian J. Marine Sci. 38: 249-256. Santamaria R.I., G. Del Rio, G. Saab, M.E. Rodriguez, X. Soberon and A. Lopez Marguia. 1999. Alcoholysis reactions from starch with alpha-amylases. FEBS Lett. 452: 346-350.

Savitri A.N. and W. Azmi. 2003. Microbial L asparaginase: A potent antitumor enzyme. Indian. J. Biotechnol. 2: 184-194.

Senthilkumar S.R., B. Ashokkumar, K. Raj Chandra and P. Gunasekaran. 2005. Optimization of medium composition for alkali-stable xylanase production by Aspergillus fischeri Fxn 1 in solid state fermentation using central composite rotary design. Bioresour Technol. 96: 1380-1386.

Shirling E.B. and D. Gottlieb. 1966. Methods for characterization of Streptomyces species. Int. J. Syst. Bacteriol. 16: 313-340.

Venil C.K., K. Nanthakumar, K. Karthikeyan and P. Lakshmanaperumalsamy. 2009. Production of L-asparaginase by Serratia marcescens SB08: Optimization by response surface methodology. Iranian J. Biotechnol. 7: 10-18.

Wang Y.X. and Z.X. Lu. 2005. Optimization of processing parameters for the mycelial growth and extracellular polysaccharide production by Boletus spp. ACCC 50328. Process Biochem. 40: 1043-1051.

Wriston J.C and T.O. Yellin. 1973. L-asparaginase: a review. Adv. Enzymol. 39: 185-248. 